Management Control 


\section{Studies in Management}

General Editor: SAMUEL EILON, D.SC (ENG), PH.D, D.I.C, F.I.MECH.E, F.I.PROD.E. Professor of Industrial and Management Engineering, Imperial College, London

NETWORK ANALYSIS

for Planning and Scheduling

EXERCISES IN INDUSTRIAL MANAGEMENT

$A$ Series of Case Studies

APPLIED QUEUEING THEORY

SYSTEMS ANALYSIS FRAMEWORKS

EXPLORATIONS IN MANAGERIAL ECONOMICS

Productivity, Costs, Technology and Growth

MATHEMATICAL PROGRAMMING

for Business and Industry

WORK MEASUREMENT

Some Research Studies

MANAGEMENT CONTROL
A. Battersby

S. Eilon, R. I. Hall, and J. R. King

A. M. Lee

A. M. Lee

Bela Gold

K. Brian Haley

N. A. Dudley

S. Eilon 


\section{Management Control}

Samuel Eilon 
(C) SAMUEL EILON I97I

Softcover reprint of the hardcover $4^{\text {th }}$ edition 1971

First Published r97 I

All rights reserved. No part of this publication may be reproduced or transmitted, in any form or by any means, without permission.

SBN $\begin{array}{llll}333 & 129 & 385\end{array}$

ISBN 978-1-349-01283-1 ISBN 978-1-349-01281-7 (eBook)

DOI 10.1007/978-1-349-01281-7

Published by

MACMILLAN AND CO LTD

London and Basingstoke

Associated companies in New York, Melbourne, Toronto, Dublin, Fohannesburg and Madras 
To Hannah

who knows how to argue and who is very often right 


\section{Preface}

When the idea of writing a book on management control was suggested to me, my first reaction was that of reluctance. I confess that I have always found the vast literature on management theory and practice a serious obstacle in my studies in this field. The sheer amount of the material presented to us over the past two decades is bewildering enough, but it is not the amount alone that made me hesitate. On scanning through the literature it appears that almost every conceivable viewpoint has already been presented, almost every theoretical framework has been explored. The formidable array of knowledgeable and sophisticated authors that have made their mark on the literature should make anyone wonder whether there is anything significantly new to add to what has already been said.

And yet over the years I have become increasingly conscious of the fact that most treatises on management organisation and theory lack an adequate appreciation of the concept of control and the central role that it must play in the management task. This is not to say that control is completely ignored in the literature. Indeed, many writers devote lengthy passages to it. But with the exception of the few who have adopted a cybernetic approach, the term control is often superficially defined, sometimes even misused.

I have, therefore, decided to concentrate on particular aspects of management control. The book is not intended as a comprehensive textbook, nor is it an attempt to provide a critical review of the way in which the concept of control is treated in the literature. Where I quote other authors it is merely with the purpose of indicating agreement of approach or highlighting contrasting views and not with the intention of listing even the most relevant contributors to this subject.

Chapter I is devoted to identifying the management task as a control process, and several concepts relating to the management of systems and their organisation structure are introduced. The manager is seen as a controller of a system and his relationships with the system and with other controllers are therefore of fundamental importance to the design and 
maintenance of control procedures. These relationships are discussed in Chapters 2 and 3 and the special case of the two-state system is analysed in some detail in Chapter 4. Since the management process manifests itself in information flow through the system, Chapters 5 and 6 are devoted to information processing and to the discussion of various types of messages that are found in the system. Chapter 7 returns to the examination of the decision process and Chapter 8 discusses the extent to which decisions can become prescriptive and be affected by constraints. Chapter 9 continues to discuss the question of constraints and whether they should be distinguished from the proclaimed goals of the decision process and, finally, Chapter Io includes some observations on theories of organisation structure.

Thus, the book has a limited objective, namely to discuss some of the important ingredients involved in the management process and to suggest fundamental concepts associated with the control function. My hope is that the discussion presented here will be of some value to students of management theory, irrespective of which discipline or school of thought they happen to represent.

Although I have been interested in management control for many years; it was in $1967-69$ that I first had an opportunity to devote sufficient time to research in this field under the auspices of the Department of Economics at Case Western Reserve University in Cleveland, where I spent some time as a Professorial Research Fellow. To Professor Gold, the Chairman of the Department of Economics, I owe a debt of gratitude for his friendship, encouragement and hospitality.

In writing this book I have drawn heavily on several papers that I have written in recent years and a list is given below. I wish to thank the publishers of these papers for permission to reproduce and to quote from them.

'Problems in studying management control', (1962) The International Journal of Production Research, I, pp. 13-20.

'Control systems with several controllers', (I965) Journal of Management Studies, 2, pp. 259-68.

'A classification of administrative control systems', (1966) Journal of Management Studies, 3, pp. 36-48.

With J. Woodward (Ig66) 'Studies in management control', Operational Research and the Social Sciences, edited by J. R. Lawrence, Tavistock Publications, pp. 95-107.

'Some notes on information processing', (I968) Journal of Management Studies, 5, pp. I39-153.

'Taxonomy of communications', (I968) Administrative Science Quarterly, 13, pp. 266-88. 
'Linkages between controllers', (I969) Journal of Management Studies, 6, pp. 45-52.

'Prescription in management decisions', (1969) Journal of Management Studies, 6, pp. I8I-97.

'What is a decision', (1969) Management Science, r6, pp. I72-89.

'Correspondence between a system and its controllers', (1970) Journal of Management Studies, 7, pp. 105-I9.

'Relationships between controllers of a system', (I970) Nature, 227, pp. 233-8. 


\section{Contents}

Preface vii

I Management, systems and control I

2 Correspondence between a system and its controllers 35

3 Control systems with several controllers $5 \mathrm{I}$

4 Control of a two-state system 69

5 Notes on information processing 97

6 Taxonomy of communications II6

7 What is a decision? I35

8 Prescription in management decisions $\quad$ I63

9 Goals and constraints $\quad$ I82

Io Structure and determinism I94

Index 205 